\title{
VII Ogólnopolskie Seminarium Prawa Ochrony Zabytków dla młodych naukowców, doktorantów i studentów im. Profesora Jana Pruszyńskiego Lubostroń, 17-19 września 2020
}

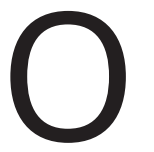
gólnopolskie Seminarium Prawa Ochrony Zabytków dla młodych naukowców, doktorantów i studentów im. Profesora Jana Pruszyńskiego na stałe zapisało się w kalendarzu wydarzeń naukowych. Od siedmiu lat gromadzi ono w jednym miejscu szerokie grono wybitnych przedstawicieli nauki, którzy zajmują się prawem ochrony zabytków oraz młodych pasjonatów właśnie tej gałęzi prawa. Co roku osoby zajmujące się tematyką dziedzictwa kulturowego mają szansę wymienić swoje poglądy, podyskutować i poszerzyć swoją wiedzę w trakcie seminarium, które do tej pory zawsze organizowane było w niezwykle urokliwym miejscu, jakim jest pałac w Lubostroniu. W związku z trwającym stanem pandemii COVID-19 w 2020 roku, inaczej niż w latach ubiegłych, uczestnicy konferowali w dniach 17-19 września z własnych domów za pośrednictwem środków komunikacji na odległość.

VII Ogólnopolskie Seminarium Prawa Ochrony Zabytków dla młodych naukowców, doktorantów i studentów im. Profesora Jana Pruszyńskiego zorganizowane pozostało przez Wydział Prawa i Administracji Uniwersytetu Gdańskiego, Wydział Prawa i Administracji Uniwersytetu Opolskiego, Wydział Prawa i Administracji Uniwersytetu im. Adama Mickiewicza w Poznaniu, Centrum Prawa Ochrony Dóbr Kultury UNESCO Uniwersytetu Opolskiego oraz Pałac Lubostroń. Parterami wydarzenia byli: Wydawnictwo Uniwersytetu Gdańskiego, Narodowy Instytut Muzealnictwa i Ochrony Zbiorów oraz Okręgowa Izba Radców Prawnych w Bydgoszczy. Patronat honorowy nad wydarzeniem objął rektor Uniwersytetu Opolskiego 
prof. Marek Masnyk. W ciągu trzech dni czternastu prelegentów z ośmiu ośrodków akademickich przedstawiło swoje referaty w czterech panelach konferencyjnych.

Pierwszego dnia konferencji odbyły się dwa wystąpienia gościnne. Profesor Ryszard Nowicki przybliżył historię oraz znaczenie biblioteki miejskiej w Bydgoszczy, natomiast Luis Javier Capote Pérez, doktor prawa i profesor na Uniwersytecie La Laguna w San Cristóbal de La Laguna na Teneryfie, zaprezentował referat pt. The Picasso case - cultural property export regulations. Private ownership vis public interest.

Drugiego dnia konferencji, po zabraniu głosu przez przedstawicieli komitetu organizacyjnego, w którego składzie znaleźli się: prof. Kamil Zeidler i dr Alicja Jagielska-Burduk oraz dyrektor Pałacu Lubostroń - Andrzej Budziak, nastąpiła inauguracyjna część konferencji - prof. Piotr Stec z Uniwersytetu Opolskiego w swoim wykładzie poruszył bliski wszystkim temat dostępu do kultury w czasach pandemii COVID-19. Następnie dr Alicja Jagielska-Burduk przedstawiła dorobek czasopisma "Santander Art and Culture Law Review”.

Po części inauguracyjnej rozpoczął się pierwszy panel konferencji, któremu przewodniczył dr Mateusz Pszczyński. Mgr Paula Chmielowska wygłosiła referat, w którym przedstawiła tezę o funkcjonowaniu ochrony dziedzictwa kultury w starożytnym Egipcie. Mgr Krzysztof Grzegorczyk omówił zarząd sukcesji kolekcji prywatnej na wypadek śmierci kolekcjonera. Mgr Olivia Koperska poruszyła kwestię wykorzystania modelu BIM w kontekście zabytków. Ostatnia prelegentka tego panelu, mgr Inga Owczarek, w swoim referacie skupiła się na temacie prawa do twórczości artystycznej.

Drugi panel konferencji, prowadzony przez dr Małgorzatę Węgrzak i dra Jakuba Chowańca, koncentrował się głównie na temacie wartości zabytku. Katarzyna Kruszewska omówiła czynną funkcję dziedzictwa kulturowego w kontekście wartości przeszłości i wartości, jaką jest piękno natury. Katarzyna Frątczak w swoim wystąpieniu skupiła się przede wszystkim na wartości zabytków architektury i designu, które powstały w XX wieku. Ostania prelegentka tego panelu, mgr Agata Lizak, przedstawiła problem wprowadzenia przestrzennych form ochrony zabytków.

Po krótkiej przerwie odbył się ostatni tego dnia panel konferencji, podczas którego dr Żaneta Gwardzińska przybliżyła problemy interpretacji prawa przez muzealników oraz potrzebę opracowania nowej ustawy o muzeach. Dr Jakub Chowaniec omówił istotną dla rozwoju dziedzictwa kwestię podatków w sektorze kultury. Dr Szymon Krajnik w swoim referacie przedstawił problem własności skradzionego lub przywłaszczonego zabytku ruchomego w przypadku jego nabycia od osoby nieuprawnionej, posiłkując się przykładem zabytkowych numizmatów. Dr Katarzyna Schatt-Babińska przybliżyła wyniki wywiadów dotyczących ochrony zabytków nieruchomych, przeprowadzonych z osobami, które są pośrednio związane z zabytkiem, tj. architektami, konserwatorami, kierownikami nadzoru i społecznymi opie- 
kunami zabytków. Drugi dzień konferencji tradycyjnie kończył się uroczystą kolacją połączoną $\mathrm{z}$ aukcją dzieł sztuki. W związku ze zdalną formą seminarium ta część musiała zostać pominięta.

Ostatniego dnia konferencji odbył się jeden panel, podczas którego Maria Hałasa zaprezentowała referat pt. Działania podmiotów ponadnarodowych oraz działania na poziomie poszczególnych państw mające na celu regulację obrotu dobrami kultury. Mgr Aleksandra Guss podjęła się próby odpowiedzi na pytanie, czy lista skarbów dziedzictwa jest potrzebną formą ochrony zabytków.

Ostatni, tradycyjny punkt seminarium, jakim był konkurs znajomości prawa ochrony zabytków, w 2020 roku został pominięty ze zrozumiałych względów. Zarówno organizatorzy, jak i uczestnicy wyrazili nadzieję, że kolejne, VIII Ogólnopolskie Seminarium Prawa Ochrony Zabytków dla młodych naukowców, doktorantów i studentów im. Profesora Jana Pruszyńskiego będzie mogło odbyć się w normalnych warunkach - w urokliwym pałacu w Lubostroniu. 